\title{
Study of the correlation between the composition, structure and crystallization in frits designed for single fast-firing glazes with variable $\mathrm{BaO}$ content
}

\author{
Marcin Gajek ${ }^{1}$
}

Received: 30 July 2019 / Accepted: 25 October 2019 / Published online: 7 November 2019

(c) The Author(s) 2019

\begin{abstract}
The paper presents the results of investigation on the development of frits for single fast-firing glazes with variable $\mathrm{BaO}$ content based on the $\mathrm{SiO}_{2}-\mathrm{Al}_{2} \mathrm{O}_{3}-\mathrm{CaO}-\mathrm{MgO}-\mathrm{ZnO}-(\mathrm{BaO})$ system, fired at a maximum temperature of $1220{ }^{\circ} \mathrm{C}$. The study of the correlation between the composition, structure and crystallization of frits and glazes was carried out using various methods for materials characterization, including differential scanning calorimetry (DSC), dilatometry (DIL), hot-stage microscopy (HSM), X-ray diffraction and scanning and transmission electron microscopy. DSC and X-ray diffraction showed a high tendency to crystallize the tested frits. DSC curves showed that all glazes crystallized during heating in a narrowtemperature range $\approx 938-955{ }^{\circ} \mathrm{C}$, and the introduction of $\mathrm{BaO}$ shifted the maximum of exothermic peaks toward higher temperatures. X-ray analysis revealed the presence of diopside and anorthite as the main crystalline phases. The introduction of 5 mass $\% \mathrm{BaO}$ to the frit composition promoted the crystallization of the additional crystalline phase of barium feldspar $\left(\mathrm{BaAl}_{2} \mathrm{Si}_{2} \mathrm{O}_{8}\right)$. In addition, in this composition a strong exothermic effect on the DSC curve at the cooling stage was observed. The analysis of data obtained from thermal studies also showed that the addition of $\mathrm{BaO}$ to the chemical composition of the frits resulted in a decrease in the glass transition temperature $\left(T_{\mathrm{g}}\right)$ and in reduction in viscosity calculated on the basis of the Vogel-Fulcher-Tammann equation (HSM, DIL).
\end{abstract}

Keywords Fritted glazes $\cdot$ Glass $\cdot \mathrm{BaO} \cdot$ Structure $\cdot$ Thermal analysis

\section{Introduction}

It is known that glazes used in ceramic products play a decorative role and numerous protective functions, including protecting the material against soaking (staining) and harmful effects of chemicals [1-3]. Glazes provides also mechanical resistance, protecting the material against adverse surface abrasion among others. Glazes differ in composition, depending on the type of material, production technology, time and temperature of firing, and one of the criteria for the division of glazes is the division into raw and fritted glazes. Raw glazes are used, for example, for the production of sanitary products [3-5] or porcelain, and they are composed of

Marcin Gajek

mgajek@agh.edu.pl

1 Faculty of Materials Science and Ceramics, AGH University of Science and Technology, al. Mickiewicza 30, 30-059 Kraków, Poland unprocessed ceramic raw materials, whereas fritted glazes contain a significant addition of frits (melted raw materials), often reaching almost $100 \%$. In the case of products fired in short times, where the whole firing process lasts less than 1-2 $\mathrm{h}$, the most frequently used glazes are made entirely of frits $[6,7]$.

Glazes with a high gloss level are particularly useful in the production of wall tiles, due to the fact that they are usually characterized by lower abrasion resistance and lower microhardness [8]. Matt or semi-matte glazes are mostly used for floor tiles, and matt glazes are usually glass-crystalline materials characterized also by increased resistance to abrasion.

Depending on the frits used, it is possible to obtain smooth surfaces with a high gloss level [9] or even matt, glass-crystalline ones [8]. There are a number of works on various glass systems such as $\mathrm{CaO}-\mathrm{MgO}-\mathrm{SiO}_{2}$ [10, 11], $\mathrm{CaO}-\mathrm{MgO}-\mathrm{Al}_{2} \mathrm{O}_{3}-\mathrm{SiO}_{2}$ [11-15], $\mathrm{Li}_{2} \mathrm{O}-\mathrm{CaO}-\mathrm{MgO}-\mathrm{Al}_{2} \mathrm{O}_{3}-\mathrm{SiO}_{2}$ [11, 16], $\left(\mathrm{Na}_{2} \mathrm{O}\right.$, $\left.\mathrm{K}_{2} \mathrm{O}, \mathrm{ZrO}_{2}, \mathrm{ZnO}\right)-\mathrm{CaO}-\mathrm{MgO}-\mathrm{Al}_{2} \mathrm{O}_{3}-\mathrm{SiO}_{2}[14,15,17-22]$, 
$\mathrm{CaO}-\mathrm{ZrO}_{2}-\mathrm{SiO}_{2}$ [11] or $\mathrm{MgO}-\mathrm{Al}_{2} \mathrm{O}_{3}-\mathrm{SiO}_{2}$ [15, 23-25]. Each of the studied system is characterized by specific, individual properties that may also be attractive in terms of their use as potential ingredients in glaze compositions. $\mathrm{BaO}$ similar to $\mathrm{CaO}, \mathrm{SrO}$ and $\mathrm{MgO}$ acts as a flux in ceramic glazes and frites, but only when fired above $1100{ }^{\circ} \mathrm{C}$, while below this temperature, $\mathrm{BaO}$ can act as an inhibitor, increasing viscosity and promoting crystallization [2]. The addition of $\mathrm{BaO}$ increases the density and index of refraction that increases the gloss, also improves the flexibility and mechanical properties of glazes and reduces the coefficient of thermal expansion $[2,3]$, which is important when designing glaze compositions. $\mathrm{BaO}$ is usually introduced in the form of $\mathrm{BaCO}_{3}$, but due to high toxicity is preferred to introduce it into glazes composition by frits [1-3].

The glasses containing large amounts of $\mathrm{BaO}$, in which celsian crystallization occurred, are characterized by low coefficient of thermal expansion (CTE) at the level of $40 \cdot 10^{-7} \mathrm{~K}^{-1}$ [26-28]. And so, in glasses with a high $\mathrm{BaO}$ content, up to 25.7 mass\% and the presence of 11.4 mass\% $\mathrm{TiO}_{2}$, after a treatment time of 2 and $6 \mathrm{~h}$, respectively, a glass-crystalline material with a thermal expansion coefficient of $4.1 \cdot 10^{-6} \mathrm{~K}^{-1}$ was obtained, in which the main phases were celsian, tielite $\left(\mathrm{Al}_{2} \mathrm{TiO}_{5}\right)$ and mullite [29]. Another example is a glass-crystalline material with a CTE in the range of $4-8 \cdot 10^{-6} \mathrm{~K}^{-1}$ consisting of celsian, enstatite and protoenstatite crystalline phases. This material was obtained from glass from the $\mathrm{BaO}-\mathrm{TiO}_{2}-\mathrm{MgO}-\mathrm{Al}_{2} \mathrm{O}_{3}-\mathrm{SiO}_{2}$ system with a $\mathrm{BaO}$ content of $15-22$ mass $\%$ and $\mathrm{TiO}_{2}$ in the range of 5-8 mass\%, which was used as a nucleating agent [30]. In the examined glasses [29, 30], the amount of $\mathrm{BaO}$ introduced exceeded 10 mass\%, which is unfavorable when using frits for glazes, mainly due to economic reasons.

The process of firing ceramic glazed tiles is usually carried out in less than $60 \mathrm{~min}$ and is much shorter compared to the firing time of traditional glazed ceramics or the thermal treatment of glass-crystalline materials lasting from a few to several hours. Therefore, this work aimed at investigating and analyzing the influence of $\mathrm{BaO}$ content on the structure and the crystallization process of fast-firing glazes based on glasses from the $\mathrm{SiO}_{2}-\mathrm{Al}_{2} \mathrm{O}_{3}-\mathrm{CaO}-\mathrm{MgO}-\mathrm{ZnO}-(\mathrm{BaO})$ system.

\section{Experimental}

\section{Materials and methods}

It is important to note that in this work, the term frit was used in relation to melted glasses, which were denoted: $\mathrm{G}$ $0, \mathrm{G} 1.0 \mathrm{Ba}, \mathrm{G} 2.5 \mathrm{Ba}, \mathrm{G} 5.0 \mathrm{Ba}$, respectively, while the term glaze (as a traditional set of ingredients introduced in the form of an aqueous suspension) refers to samples prepared in $100 \%$ of melted frits. The frits were prepared from commercially available materials: $\mathrm{SiO}_{2}, \mathrm{Al}_{2} \mathrm{O}_{3}, \mathrm{MgO}, \mathrm{ZnO}, \mathrm{CaCO}_{3}$ and $\mathrm{BaCO}_{3}$ of high purity ( $>99.5 \%$ ), and their compositions are listed in Table 1.

The homogenized batches of raw materials for frits in the amount of $150 \mathrm{~g}$ each were melted in platinum crucibles in an electric furnace at $1400{ }^{\circ} \mathrm{C}$ for $2 \mathrm{~h}$. The fluid melt was quenched by pouring onto a steel plate to obtain a glassy frit. Then, part of the frit was pulverized in a mechanical agate mortar (Fritsch Pulverisette 2) and then screened with a standard 230-mesh sieve. Thus, a powder with particle size smaller than $63 \mu \mathrm{m}$ was obtained (for each produced frits) and used to prepare samples for further testing.

Frits in the form of a powder were required to determine the chemical composition and confirm the non-crystalline structure of the obtained frits, as well as thermal properties. An analysis of the chemical composition of the frits was carried out using a WDXRF (wavelength-dispersive X-ray fluorescence) Axios mAX spectrometer supplied by PANalytical. To investigate the amorphous nature of the obtained frits, powdered frits samples were analyzed by an X-ray analysis using an X'Pert Pro X-ray diffractometer manufactured by Philips (PANalytical). Thereafter, frits were observed using transmission electron microscope (TEM) Jeol-JEM 1011. (100 kV accelerating voltage was used.)

The crystallization capability of frits obtained was tested by thermal method (DSC - differential scanning calorimetry) using a STA 449 F3 Jupiter (Netzsch) simultaneous thermal analyzer on powder samples with a grain size below $63 \mu \mathrm{m}$. The measurement was taken in platinum crucibles on $50 \mathrm{mg}$ samples in an air atmosphere (flow $40 \mathrm{~mL} \mathrm{~min}^{-1}$ ), heated at a rate of $10{ }^{\circ} \mathrm{C} \mathrm{min}^{-1}$ to $1220{ }^{\circ} \mathrm{C}$, and after reaching this temperature, the measurement was continued by cooling the system to $600{ }^{\circ} \mathrm{C}$.
Table 1 Composition of frits in mass\%

\begin{tabular}{lllllll}
\hline No & \multicolumn{2}{l}{ Content of components/mass\% } & & \\
\cline { 2 - 6 } & $\mathrm{SiO}_{2}$ & $\mathrm{Al}_{2} \mathrm{O}_{3}$ & $\mathrm{CaO}$ & $\mathrm{MgO}$ & $\mathrm{ZnO}$ & $\mathrm{BaO}$ \\
\hline $\mathrm{G} \mathrm{0}$ & 48.18 & 18.90 & 19.21 & 9.53 & 4.18 & - \\
$\mathrm{G} 1.0 \mathrm{Ba}$ & 47.70 & 18.71 & 19.01 & 9.44 & 4.13 & 1.01 \\
$\mathrm{G} 2.5 \mathrm{Ba}$ & 46.97 & 18.42 & 18.73 & 9.29 & 4.07 & 2.51 \\
$\mathrm{G} 5.0 \mathrm{Ba}$ & 45.77 & 17.95 & 18.25 & 9.06 & 3.96 & 5.02 \\
\hline
\end{tabular}


Determination of thermal expansion coefficient and calculation of viscosity of tested frits were performed on the basis of measurements taken by means of a mechanical dilatometer and a high-temperature microscope. Coefficient of thermal expansion (CTE), transformation temperature $\left(T_{\mathrm{gd}}\right)$ and dilatometric softening point $\left(T_{\mathrm{s}}\right)$ were determined using a dilatometer DL $402 \mathrm{C}$ (Netzsch) on $10 \times 3 \times 3 \mathrm{~mm}$ solid (bulk) samples. Hemispherical temperatures $\left(T_{\mathrm{hs}}\right)$ and melting temperature $\left(T_{\mathrm{m}}\right)$ were determined on the powdered material using a hot-stage microscope (HSM) (Misura). Test samples of cylindrical form with a diameter of $2 \mathrm{~mm}$ and a height of $3 \mathrm{~mm}$ were prepared from uniaxially pressed material and heated from room temperature up to $1300{ }^{\circ} \mathrm{C}$ at a heating rate of $10^{\circ} \mathrm{C} \mathrm{min}^{-1}$. The characteristic temperatures such as the half-sphere temperature $T_{\mathrm{hs}}$ (temperature at which the height is equal to half the base of the sample) and the melting temperature $T_{\mathrm{m}}$ (temperature for which the sample is melted down to one-third of its initial height) were determined. The viscosity of glasses was calculated according to the equation proposed by Vogel-Fulcher-Tammann (VFT) on the basis of results from dilatometer and HSM microscopy [31].

To investigate the glaze microstructure after the firing process, a slurry of ground frits with a density of $1.6 \mathrm{~g} \mathrm{~cm}^{-3}$ was prepared by mixing powders with water and the addition of carboxymethylcellulose (CMC). Aqueous suspensions of glazes were applied by spraying onto a porcelain tile to produce a coating with a thickness of $\approx 0.6 \mathrm{~mm}\left(0.1 \mathrm{~g} \mathrm{~cm}^{-2}\right)$. The prepared samples were heat-treated in an electric furnace at $1220{ }^{\circ} \mathrm{C}$ for $4 \mathrm{~min}$ with heating and cooling rates of $50{ }^{\circ} \mathrm{C} \mathrm{min}{ }^{-1}$. Microstructural observations as well as the EDAX analysis in microregions were performed on the polished cross sections of materials with the use of a Nova NanoSEM 200 scanning electron microscope (FEI Europe).

The evolution of crystalline phases developed in glazes after firing process was determined by X-ray diffraction. For this purpose, samples with a diameter of $25 \mathrm{~mm}$ and a height of $1 \mathrm{~mm}$ were pressed from powdered frits, and thus, prepared samples were fired in a fast-firing cycle described above. The additional samples were subjected to a firing process, and after reaching the crystallization temperatures $T_{\mathrm{c}}$ and the maximum firing temperature $\left(1220^{\circ} \mathrm{C}\right)$, the samples were removed from the furnace and rapidly cooled down to freeze the system. Samples prepared in such a way allowed for immediate cooling of the system. Materials subjected to this thermal treatment were then ground to a grain size below $63 \mu \mathrm{m}$, and the crystalline structure of the samples was identified by an X-ray analysis using an X'Pert Pro $\mathrm{X}$-ray diffractometer manufactured by Philips (PANalytical).

\section{Results and discussion}

All melted glasses intended for frits were homogeneous and visually transparent after melting and pouring on a steel plate. Thus, prepared material was then ground and subjected to further tests.

Transmission electron microscopy was used to observe the morphology of materials, and Fig. 1 shows TEM images of ground frits.

The TEM micrographs of all ground frits did not reveal the lack of homogeneity and unreacted substrates, and no phase separation phenomenon was observed.

Figure 2 shows the DSC curves, while Table 2 summarizes the thermal properties determined on the basis of thermal analysis (DSC), dilatometric measurements (DL) and high-temperature microscopy (HSM).

The transformation temperature $T_{\mathrm{g}}$ determined from the thermal curves DSC related to the viscosity of the glass [32] slightly decreases for frits, for which up to 2.5 mass\% of $\mathrm{BaO}(\mathrm{G} 1.0 \mathrm{Ba}$ and $\mathrm{G} 2.5 \mathrm{Ba}$ ) was introduced in relation to the $\mathrm{G} 0$ frit. In the frit with 5 mass $\% \mathrm{BaO}$ content (G 5.0Ba), a slight increase in the transformation temperature was observed. A similar behavior was noticed for the same frits with respect to the transformation temperature $T_{\mathrm{gd}}$ determined using a mechanical dilatometer.

Strong exothermic effects were observed on the thermal curves (DSC) in the temperature range of $938-955^{\circ} \mathrm{C}$ during heating of samples, which indicates the crystallization of new crystalline phases. The maximum exothermic effect shifted to higher temperatures with increasing $\mathrm{BaO}$ content, which is most visible in the sample with 5 mass\% of $\mathrm{BaO}$ content $(\mathrm{G} \mathrm{5.0Ba})$, where the shift was $17{ }^{\circ} \mathrm{C}$. The onset of endothermic effect, indicating the melting of crystalline
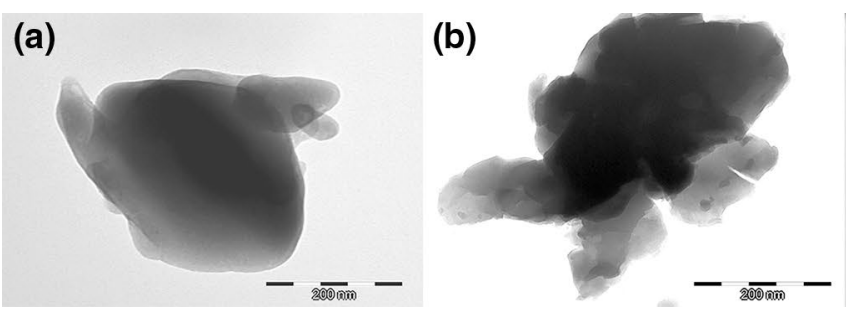

(c)

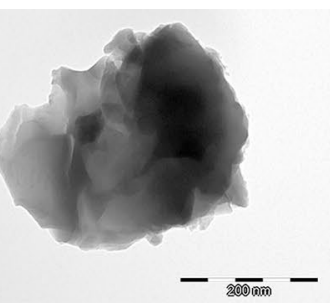

(d)

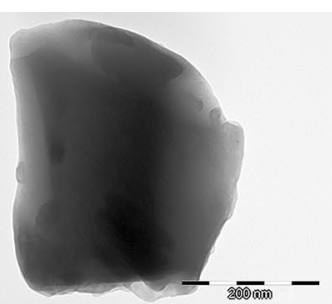

Fig. 1 TEM micrographs of the frits; a G 0, b G 1.0Ba, c G 2.5Ba, d G 5.0Ba 


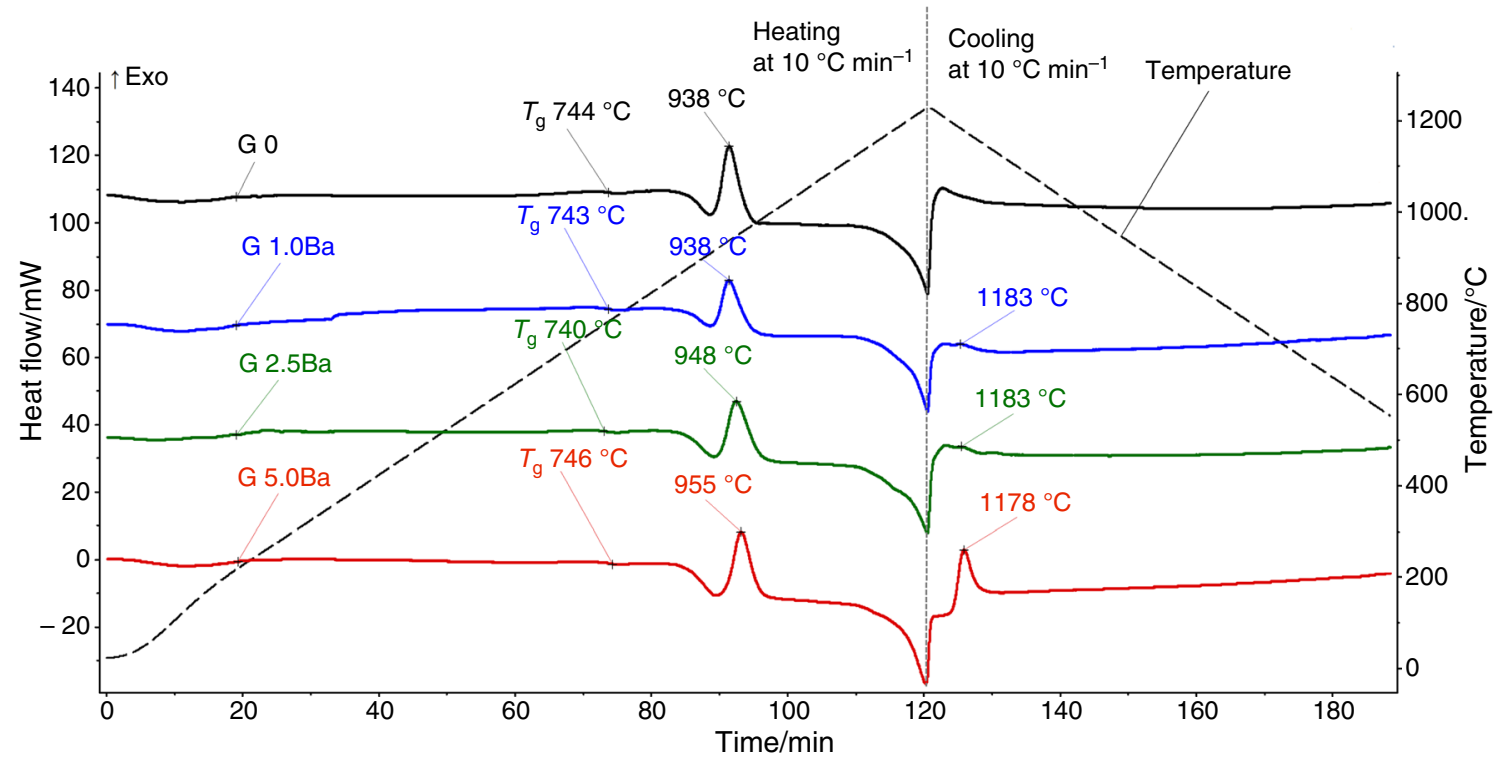

Fig. 2 DSC curves of studied frits

Table 2 Thermal properties of frits in the $\mathrm{SiO}_{2}-\mathrm{Al}_{2} \mathrm{O}_{3}-\mathrm{CaO}-\mathrm{MgO}-$ $\mathrm{ZnO}-(\mathrm{BaO})$ system

\begin{tabular}{|c|c|c|c|c|}
\hline Measurement technique & G 0 & $\mathrm{G} 1.0 \mathrm{Ba}$ & $\mathrm{G} 2.5 \mathrm{Ba}$ & $\mathrm{G} 5.0 \mathrm{Ba}$ \\
\hline \multicolumn{5}{|l|}{ DL (dilatometer) } \\
\hline Transition $-T_{\mathrm{gd}} /{ }^{\circ} \mathrm{C}$ & 743 & 742 & 735 & 740 \\
\hline Softening $-T_{\mathrm{s}} /{ }^{\circ} \mathrm{C}$ & 778 & 776 & 771 & 777 \\
\hline $\begin{array}{l}\mathrm{CTE}\left(50-500{ }^{\circ} \mathrm{C}\right) / 10^{-6} \\
\mathrm{~K}^{-1}\end{array}$ & 6.3 & 6.5 & 6.4 & 6.4 \\
\hline \multicolumn{5}{|c|}{ HSM (hot-stage microscope) } \\
\hline Half-sphere $-T_{\mathrm{hs}}{ }^{\circ} \mathrm{C}$ & 1276 & 1263 & 1243 & 1237 \\
\hline Melting $-T_{\mathrm{m}} /{ }^{\circ} \mathrm{C}$ & 1281 & 1268 & 1250 & 1245 \\
\hline \multicolumn{5}{|c|}{ DSC (differential scanning calorimetry) } \\
\hline Transition $-T_{\mathrm{g}} /{ }^{\circ} \mathrm{C}$ & 744 & 743 & 740 & 746 \\
\hline $\begin{array}{l}\text { Crystallization effect- } \\
T_{\mathrm{c}} /{ }^{\circ} \mathrm{C}\end{array}$ & 938 & 938,1183 & 948,1183 & 955,1178 \\
\hline
\end{tabular}

phases was observed on the DSC curves in all samples at $1120{ }^{\circ} \mathrm{C}$. In the cooling stage, in samples of the $\mathrm{G} 1.0 \mathrm{Ba}$ and $\mathrm{G} 2.5 \mathrm{Ba}$ frits, there were very weak exothermic effects observed at $1183{ }^{\circ} \mathrm{C}$. However, in the sample with the highest $\mathrm{BaO}$ content, a very strong exothermic effect was observed with a maximum at $1178^{\circ} \mathrm{C}$, indicating the occurrence of recrystallization at the cooling stage.

The dilatometric tests also showed a slight decrease in the transformation temperature $T_{\mathrm{gd}}$ of the tested frits (Table 2) with increasing $\mathrm{BaO}$ content. The temperature of their softening point $T_{\mathrm{s}}$ also decreased, except for the frit with the highest $\mathrm{BaO}$ content, where the softening temperature increased. There were no significant changes in the coefficient of thermal expansion with a change in $\mathrm{BaO}$ content, which was in the range $6.4-6.5 \times 10^{-6} \mathrm{~K}^{-1}$.

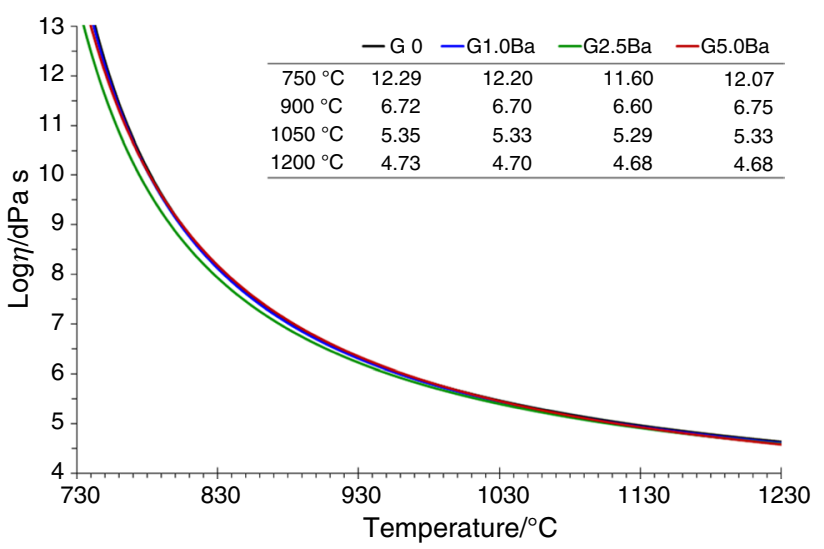

Fig. 3 The viscosity of experimental frits as a function of temperature

The viscosity curves of frits were calculated based on the Vogel-Fulcher-Tammann equation [33], using the measured temperature values (by dilatometer: $T_{\mathrm{gd}}, T_{\mathrm{s}}$, by hot-stage microscope: $T_{\mathrm{m}}$ ). The relationship of viscosity of frits as a function of temperature and viscosity values at selected temperatures is shown in Fig. 3.

The calculated viscosity of the analyzed frits indicated slight differences between individual frits, and so, the decrease in viscosity was noticeable with the increase of $\mathrm{BaO}$ content. However, the increase in $\mathrm{BaO}$ content up to 5 mass\% in G 5.0Ba frit caused a slight increase in viscosity at relatively lower temperatures (up to $1000{ }^{\circ} \mathrm{C}$ ), which resulted from the higher transformation and softening temperatures determined by means of dilatometer.

$\mathrm{X}$-ray analysis of the tested glazes was aimed at identifying the crystalline phases appearing during all stages of 
firing, i.e., the full cycle, at the maximum firing temperature, at the crystallization peak and raw frits. The XRD patterns of selected glazes G 0 and G 5.0Ba are shown in Figs. 4 and 5, and Table 3 summarizes the results of the identified crystalline phases.

The diffractograms of all studied raw frits show the elevated background, the angle $2 \Theta$ of which ranges from $15^{\circ}$ to $35^{\circ}$, indicating the existence of an amorphous phase. However, the X-ray analysis revealed the presence of anorthite (ICSD 00-041-1486) and diopside (ICSD 98-003-0522) as the main phases in all glazes at each stage of firing. Both phases were identified in glazes at the maximum temperature of the exothermic peak, i.e., in the temperature range of $938-955^{\circ} \mathrm{C}$, suggesting parallel crystallization of the identified phases in the investigated $\mathrm{SiO}_{2}-\mathrm{Al}_{2} \mathrm{O}_{3}-\mathrm{CaO}-\mathrm{MgO}-\mathrm{ZnO}-(\mathrm{BaO})$ system. The fact that there is one exothermic effect, rather than two or more, is most likely associated with a slight difference in the
Fig. 4 X-ray diffraction patterns of frit $\mathrm{G} 0\left(\mathrm{CaMg}\left(\mathrm{Si}_{2} \mathrm{O}_{6}\right)\right.$ diopside, $\mathrm{Ca}\left(\mathrm{Al}_{2} \mathrm{Si}_{2} \mathrm{O}_{6}\right)$-anorthite)
Fig. 5 X-ray diffraction patterns of $\mathrm{G} 5.0 \mathrm{Ba}$ frit $\left(\mathrm{CaMg}\left(\mathrm{Si}_{2} \mathrm{O}_{6}\right)\right.$ diopside, $\mathrm{Ca}\left(\mathrm{Al}_{2} \mathrm{Si}_{2} \mathrm{O}_{6}\right)$ - anorthite, $\mathrm{Ba}\left(\mathrm{Al}_{2} \mathrm{Si}_{2} \mathrm{O}_{6}\right)$-celsian)
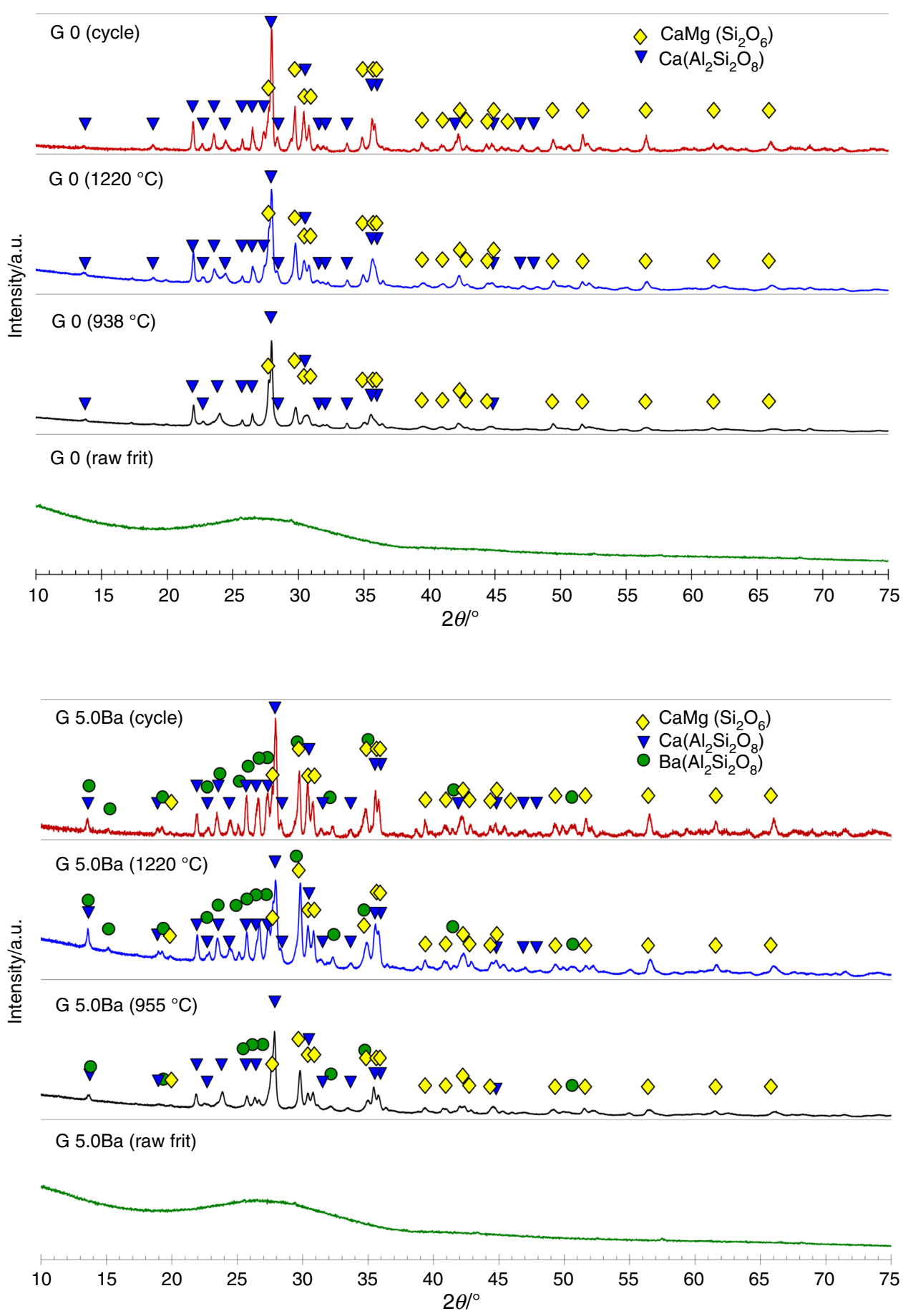
Table 3 Relative amounts of crystalline phases at different firing stages

\begin{tabular}{|c|c|c|c|c|c|c|c|}
\hline No & Raw frit & $T_{\mathrm{c}} /{ }^{\circ} \mathrm{C}$ & & $1220^{\circ} \mathrm{C}$ & & Cycle & \\
\hline \multirow[t]{2}{*}{ G 0} & Fully amorphous & $\mathrm{CaMg}\left(\mathrm{Si}_{2} \mathrm{O}_{6}\right)$ & $(+)$ & $\mathrm{CaMg}\left(\mathrm{Si}_{2} \mathrm{O}_{6}\right)$ & $(+)$ & $\mathrm{CaMg}\left(\mathrm{Si}_{2} \mathrm{O}_{6}\right)$ & $(++)$ \\
\hline & & $\mathrm{Ca}\left(\mathrm{Al}_{2} \mathrm{Si}_{2} \mathrm{O}_{8}\right)$ & $(++)$ & $\mathrm{Ca}\left(\mathrm{Al}_{2} \mathrm{Si}_{2} \mathrm{O}_{8}\right)$ & $(++)$ & $\mathrm{Ca}\left(\mathrm{Al}_{2} \mathrm{Si}_{2} \mathrm{O}_{8}\right)$ & $(+++)$ \\
\hline \multirow[t]{2}{*}{$\mathrm{G} 1.0 \mathrm{Ba}$} & Fully amorphous & $\mathrm{CaMg}\left(\mathrm{Si}_{2} \mathrm{O}_{6}\right)$ & $(+)$ & $\mathrm{CaMg}\left(\mathrm{Si}_{2} \mathrm{O}_{6}\right)$ & $(+)$ & $\mathrm{CaMg}\left(\mathrm{Si}_{2} \mathrm{O}_{6}\right)$ & $(++)$ \\
\hline & & $\mathrm{Ca}\left(\mathrm{Al}_{2} \mathrm{Si}_{2} \mathrm{O}_{8}\right)$ & $(++)$ & $\mathrm{Ca}\left(\mathrm{Al}_{2} \mathrm{Si}_{2} \mathrm{O}_{8}\right)$ & $(++)$ & $\mathrm{Ca}\left(\mathrm{Al}_{2} \mathrm{Si}_{2} \mathrm{O}_{8}\right)$ & $(+++)$ \\
\hline \multirow[t]{2}{*}{$\mathrm{G} 2.5 \mathrm{Ba}$} & Fully amorphous & $\mathrm{CaMg}\left(\mathrm{Si}_{2} \mathrm{O}_{6}\right)$ & $(+)$ & $\mathrm{CaMg}\left(\mathrm{Si}_{2} \mathrm{O}_{6}\right)$ & $(+)$ & $\mathrm{CaMg}\left(\mathrm{Si}_{2} \mathrm{O}_{6}\right)$ & $(++)$ \\
\hline & & $\mathrm{Ca}\left(\mathrm{Al}_{2} \mathrm{Si}_{2} \mathrm{O}_{8}\right)$ & $(++)$ & $\mathrm{Ca}\left(\mathrm{Al}_{2} \mathrm{Si}_{2} \mathrm{O}_{8}\right)$ & $(++)$ & $\mathrm{Ca}\left(\mathrm{Al}_{2} \mathrm{Si}_{2} \mathrm{O}_{8}\right)$ & $(+++)$ \\
\hline \multirow[t]{3}{*}{ G 5.0Ba } & Fully amorphous & $\mathrm{CaMg}\left(\mathrm{Si}_{2} \mathrm{O}_{6}\right)$ & $(+)$ & $\mathrm{CaMg}\left(\mathrm{Si}_{2} \mathrm{O}_{6}\right)$ & $(++)$ & $\mathrm{CaMg}\left(\mathrm{Si}_{2} \mathrm{O}_{6}\right)$ & $(++)$ \\
\hline & & $\mathrm{Ca}\left(\mathrm{Al}_{2} \mathrm{Si}_{2} \mathrm{O}_{8}\right)$ & $(++)$ & $\mathrm{Ca}\left(\mathrm{Al}_{2} \mathrm{Si}_{2} \mathrm{O}_{8}\right)$ & $(++)$ & $\mathrm{Ca}\left(\mathrm{Al}_{2} \mathrm{Si}_{2} \mathrm{O}_{8}\right)$ & $(+++)$ \\
\hline & & $\mathrm{Ba}\left(\mathrm{Al}_{2} \mathrm{Si}_{2} \mathrm{O}_{8}\right)$ & $(+)$ & $\mathrm{Ba}\left(\mathrm{Al}_{2} \mathrm{Si}_{2} \mathrm{O}_{8}\right)$ & $(+)$ & $\mathrm{Ba}\left(\mathrm{Al}_{2} \mathrm{Si}_{2} \mathrm{O}_{8}\right)$ & $(+)$ \\
\hline
\end{tabular}

,+++++ and + denote strong, medium and weak diffraction peaks, respectively temperature in which they occurred. Tulyaganov et al. [13] associated this effect with the degree of sample grinding, namely the more finer the sample, the stronger the suppression of the weaker peak. According to the author of this work, this was associated with the overlap of peaks, which meant that the visible was only the strongest peak, and the smaller was either not visible or hardly noticeable. In G 5.0Ba glaze, besides anorthite and diopside, celsian (ICSD 00-018-0153) was also found as an additional phase, and its presence was also confirmed by appearance of a weak peak at the $2 \Theta$ angle of $26.6^{\circ}$, at the maximum temperature of glaze crystallization, i.e., $955^{\circ} \mathrm{C}$. Although thermal analysis of $\mathrm{G} 5.0 \mathrm{Ba}$ glaze showed an additional exothermic effect at the cooling stage at $1178{ }^{\circ} \mathrm{C}$, the $\mathrm{X}$-ray diffraction pattern of the glaze from the full firing cycle did not reveal the presence of additional crystalline phase, apart from anorthite, diopside and celsian identified at temperatures of $955^{\circ} \mathrm{C}$ and $1220^{\circ} \mathrm{C}$. This indicates the recrystallization of one or more phases that was identified at the crystallization temperature of $955^{\circ} \mathrm{C}$ and at the maximum firing temperature.

The results of microstructural observations (SEM) of glazes characterized by a high degree of recrystallization are shown together with the results of EDS analysis on cross sections in Fig. 6.

It can be observed in microphotographs that the crystallites of the glazes obtained are irregular as well as in the shape of columnar or tabular grains. A slightly smaller number of crystallites were observed in glazes with an addition of 1.0 and 2.5 mass\% of $\mathrm{BaO}(\mathrm{G} 1.0 \mathrm{Ba}$ and $\mathrm{G} 2.5 \mathrm{Ba})$ and at the same time a greater amount of the amorphous phase in relation to the initial G 0 sample. The results of SEM observations indicate also that grains with irregularly shaped grains disappear with increasing $\mathrm{BaO}$ content to 2.5 mass \%; nevertheless, X-ray analysis did not reveal any changes in

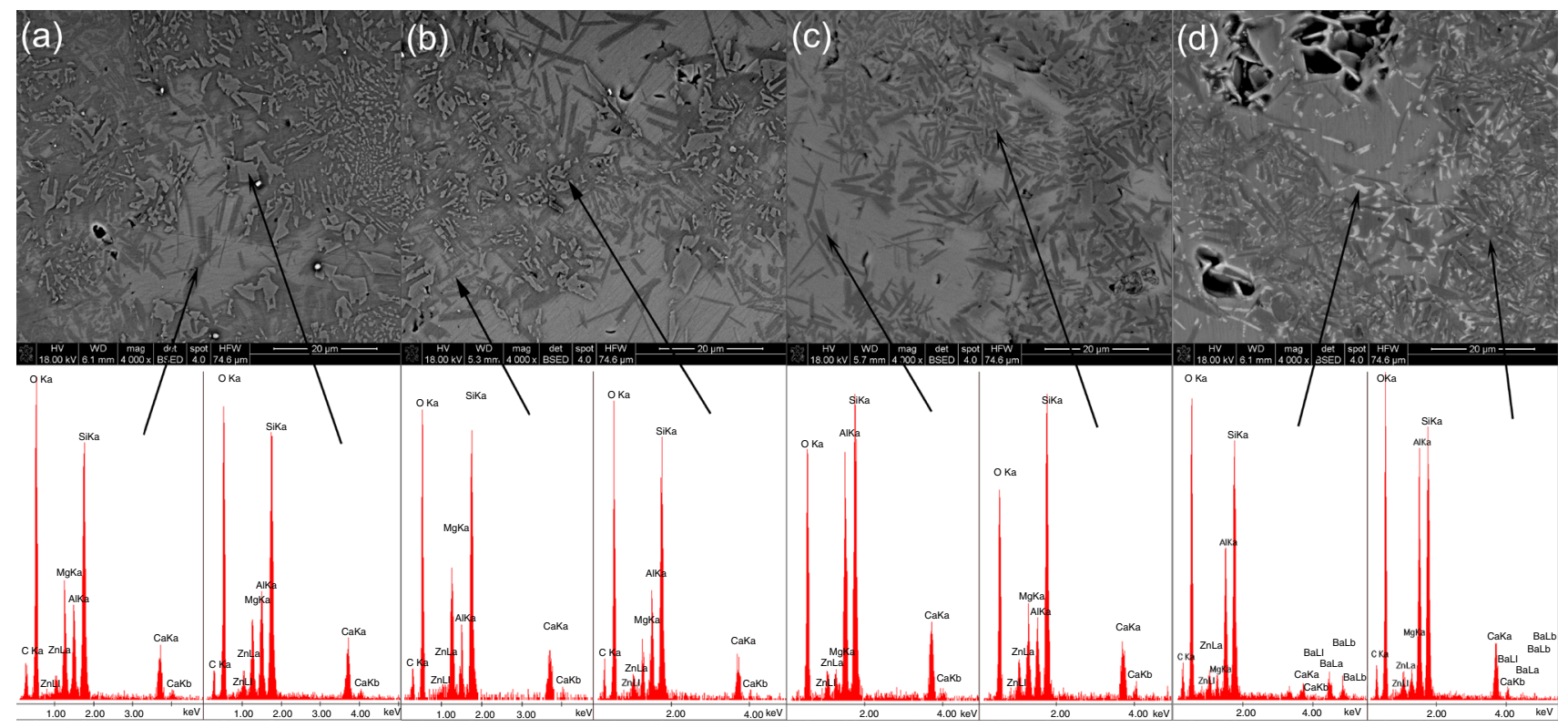

Fig. 6 SEM micrographs and EDS analysis of investigated glazes (a G 0, b G 1.0Ba, c G 2.5Ba, d G 5.0Ba) 
the phase composition of the glazes studied. In the microphotographs of the glaze with the highest 5.0 mass $\% \mathrm{BaO}$ content, grains of the crystalline phase with a lighter color and an isometric shape, which passing into columnar ones, are additionally visible. The increase in the number of crystallites was noticeably in the glaze with the addition of 5.0 mass $\% \mathrm{BaO}$, and the size of these crystallites was smaller than in glazes with lower $\mathrm{BaO}$ content. This fact can be explained by the recrystallization of phases at the cooling stage, which was confirmed by the DSC analysis. The EDS analysis of the observed crystalline phases, both columnar and irregular, showed only slight differences in chemical composition, and the only exceptions were crystallites with a lighter color in the G 5.0Ba glaze, in which the EDS analysis revealed the presence of $\mathrm{BaO}$, which clearly indicates the formation of celsian.

\section{Conclusions}

The study investigated the correlation of the composition and influence of $\mathrm{BaO}$ addition on the structure and process of crystallization of fast-firing glazes (frits) from the $\mathrm{MgO}-\mathrm{CaO}-\mathrm{Al}_{2} \mathrm{O}_{3}-\mathrm{SiO}_{2}-\mathrm{ZnO}-(\mathrm{BaO})$ system. It has been shown that $\mathrm{BaO}$ introduced in small amounts into the frit may not only affect the change in melting point or gloss level, but may also significantly affect the microstructure of the newly designed glazes.

The studied frits from the $\mathrm{MgO}-\mathrm{CaO}-\mathrm{Al}_{2} \mathrm{O}_{3}-\mathrm{SiO}_{2}-\mathrm{ZnO}-(\mathrm{BaO})$ system were characterized by a high tendency to crystallize, which was confirmed by thermal analysis, X-ray analysis and SEM observations. Strong exothermic effects recorded on DSC curves in the temperature range of $938-955{ }^{\circ} \mathrm{C}$ indicated the crystallization of new phases in the system, and the main identified phases were anorthite and diopside with irregular and columnar or plate-like shapes. The addition of $\mathrm{BaO}$ in an amount up to 2.5 mass\% resulted in a slight reduction in the number of crystallites formed, but the introduction of a higher amount of $\mathrm{BaO}$ (5 mass\%) was followed by the crystallization of a new crystalline phase, i.e., feldspar-celsian, with columnar or isometric crystals not exceeding $5 \mu \mathrm{m}$. A higher number (higher density) of crystallites in glaze with a maximum content of $\mathrm{G} 5.0 \mathrm{Ba}$ was also noticeably. Thermal studies of the $\mathrm{G} 5.0 \mathrm{Ba}$ frit also revealed the presence of a strong exothermic effect during the cooling stage at $1178^{\circ} \mathrm{C}$, which is related to the recrystallization of the phases, i.e., anorthite, diopside and celsian, also identified by XRD analysis at various stages of glaze firing. The appearance of small-sized crystallites was eventually confirmed as the effect of crystallization at the cooling stage.

It can be therefore concluded that the addition of $\mathrm{BaO}$ to glazes creates the possibility of controlling their phase composition and microstructure, which can be important when designing the performance parameters of glazes.

Acknowledgements This study was performed within the framework of funding for statutory activities of AGH University of Science and Technology in Cracow, Faculty of Materials Science and Ceramics (11.11.160.617)

Open Access This article is distributed under the terms of the Creative Commons Attribution 4.0 International License (http://creativeco mmons.org/licenses/by/4.0/), which permits unrestricted use, distribution, and reproduction in any medium, provided you give appropriate credit to the original author(s) and the source, provide a link to the Creative Commons license, and indicate if changes were made.

\section{References}

1. Stefanov S, Batschwarov S. Keramik Glasuren-ceramic glazes. Wiesbaden und Berlin: Bauverlag GmbH; 1988.

2. Eppler RA, Eplpler DA. Glazes and glass coatings. Westerville: The American Ceramic Society; 2000.

3. Fortuna D. Sanitaryware. Ceramic technology. Faenza: Gruppo Editoriale; 2000.

4. Gajek M, Partyka M, Leśniak M, Rapacz-Kmita A, Wójcik Ł. Gahnite white colour glazes in $\mathrm{ZnO}-\mathrm{R}_{2} \mathrm{O}-\mathrm{RO}-\mathrm{Al}_{2} \mathrm{O}_{3}-\mathrm{SiO}_{2}$ system. Ceram Int. 2018;44:15845-50.

5. Gajek M, Partyka M, Rapacz-Kmita A, Gasek K. Development of anorthite based white porcelain glaze without $\mathrm{ZrSiO}_{4}$ content. Ceram Int. 2017;43:1703-9.

6. Sheikhattar M, Attar H, Sharafi S, Carty WM. Influence of surface crystallinity on the surface roughness of different ceramic glazes. Mater Charact. 2016;118:570-4.

7. Casasola R, Rincón JM, Romero M. Glass-ceramic glazes for ceramic tiles-a review. J Mater Sci. 2012;47:553-82.

8. Rincon JM, Romero M. Recent advances in new type of glassceramics glazes (GCG) from natural raw materials and by recycling of industrial wastes. Key Eng Mater. 2002;206-213:887-90.

9. Pekkan K, Karasu B. Zircon-free frits suitable for single fast-firing opaque wall tile glazes and their industrial productions. J Eur Ceram Soc. 2009;29:1571-8.

10. Baldi G, Generali E, Leonelli C, Manfredini T, Pellacani GC, Siligardi C. Effects of nucleating agents on diopside crystallization in new glass-ceramics for tile-glaze application. J Mater Sci. 1995;30:3251-5.

11. Manfredini T. Ceramic tile glazes design, trends and applications. Key Eng Mater. 2002;206-213:2031-4.

12. Romero M, Rincon JM, Acosta A. Effect of iron oxide content on the crystallisation of a diopside glass-ceramic glaze. J Eur Ceram Soc. 2002;22:883-90.

13. Tulyaganov DU, Ribeiro MJ, Labrincha JA. Development of glass-ceramics by sintering and crystallization of fine powders of calcium-magnesium-aluminosilicate glass. Ceram Int. 2002;28:515-20.

14. Torres FJ, Alarcon J. Pyroxene-based glass-ceramics as glazes for floor tiles. J Eur Ceram Soc. 2005;25:349-55.

15. Rasteiro MG, Gassman T, Santos R, Antunes E. Crystalline phase characterization of glass-ceramic glazes. Ceram Int. 2007:33:345-54.

16. Rincón JM, Romero M, Marco J, Caballer V. Some aspects of crystallization microstructure on new glass-ceramic glazes. Mat Res Bull. 1998;33:1159-64. 
17. Preda M, Rehner HH. Bulk crystallized glazes in quaternary system $\mathrm{Na}_{2} \mathrm{O}-\mathrm{CaO}-\mathrm{MgO}-\mathrm{SiO}_{2}$. Key Eng Mater. 1997;132-136:2143-6.

18. Torres FJ, Ruiz de Sola E, Alarcón J. Effect of some additives on the development of spinel-based glass-ceramic glazes for floortiles. J Non-Cryst Solids. 2005;351:2453-61.

19. Alptekin $\mathrm{K}$, Kara F. Glass-ceramic glazes in the $\mathrm{CaO}-\mathrm{SiO}_{2}$ system. Key Eng Mater. 2004;264-268:1709-12.

20. Leśniak M, Gajek M, Partyka J, Sitarz M. Structure and thermal properties of the fritted glazes in $\mathrm{SiO}_{2}-\mathrm{Al}_{2} \mathrm{O}_{3}-\mathrm{CaO}-\mathrm{MgO}-\mathrm{Na}_{2} \mathrm{O}-$ $\mathrm{K}_{2} \mathrm{O}-\mathrm{ZnO}$ system. J Therm Anal Calorim. 2017;130:165-76.

21. Leśniak M, Gajek M, Partyka J, Sitarz M. Thermal characterisation of raw aluminosilicate glazes in $\mathrm{SiO}_{2}-\mathrm{Al}_{2} \mathrm{O}_{3}-\mathrm{CaO}-\mathrm{K}_{2} \mathrm{O}-$ $\mathrm{Na}_{2} \mathrm{O}-\mathrm{ZnO}$ system with variable content of $\mathrm{ZnO}$. J Therm Anal Calorim. 2017;128:1343-51.

22. Gasek K, Partyka J, Gajek M, Panna W. Characteristic of synthesis and transformations of hardystonite in willemite glass-crystalline glaze based on thermal analysis. J Therm Anal Calorim. 2016;125:1135-42.

23. Lira C, NovaesdeOliveira AP, Alarcon OE. Sintering and crystallisation of $\mathrm{MgO}-\mathrm{Al}_{2} \mathrm{O}_{3}-\mathrm{SiO}_{2}$ glass powders to produce cordierite glass ceramics. Glass Technol. 2004;45:43-8.

24. Hwang SP, Wu M. Effect of composition on microstructural development in $\mathrm{MgO}-\mathrm{Al}_{2} \mathrm{O}_{3}-\mathrm{SiO}_{2}$ glass-ceramics. J Am Ceram Soc. 2001;84:1108-12.

25. Gajek M, Lis J, Partyka J, Wójczyk M. Floor tile glass-ceramic glaze for improvement of the resistance to surface abrasion. IOP Conf Ser Mater Sci Eng. 2011;18:112016.
26. Höland W, Beall GH. Glass-ceramic technology. Hoboken, Wiley; 2012. pp. 5-32.

27. MacDowell JF. Aluminoborate glass-ceramics with low thermal expansivity. J Am Ceram Soc. 1990;73:2287-92.

28. Hovhannisyan RM. Rafaelites-new kind of glass ceramics with low thermal expansion and low melting temperatures on the basis of alkaline earth aluminium borates. Glass Technol. 2003;44:96-100.

29. Beall GH. Refractory glass-ceramics based on alkaline earth aluminosilicates. J Eur Ceram Soc. 2009;29:1211-9.

30. El-Meliegy EAM, Abdel-Hameed SAM. Enstatite-celsian glass ceramics. Mater Charact. 2005;55:28-34.

31. Fluegel A. Glass viscosity calculation based on a global statistical modelling approach. Glass Technol Eur J Glass Sci Technol A. 2007;48:13-30.

32. Varshneya AK. Fundamentals of inorganic glasses. Sheffield: Society of Glass Technology; 2006.

33. Partyka J, Gasek K, Pasiut K, Gajek M. Effect of addition of $\mathrm{BaO}$ on sintering of glass-ceramic materials from $\mathrm{SiO}_{2}$ $\mathrm{Al}_{2} \mathrm{O}_{2}-\mathrm{Na}_{2} \mathrm{O}-\mathrm{K}_{2} \mathrm{O}-\mathrm{CaO} / \mathrm{MgO}$ system. J Therm Anal Calorim. 2016;125:1095-103.

Publisher's Note Springer Nature remains neutral with regard to jurisdictional claims in published maps and institutional affiliations. 